\title{
Peroxidase activity and sensory quality of ready to cook mixed vegetables for soup: combined effect of biopreservatives and refrigerated storage
}

\author{
María Victoria ALVAREZ ${ }^{1,2 *}$, María del Rosario MOREIRA ${ }^{1,2}$, Alejandra PONCE ${ }^{1,2}$
}

\begin{abstract}
Enzymatic senescence processes and browning of fresh cut vegetables negatively affect their sensory properties and nutritional value and finally result in the rejection of affected products by consumers. In order to prevent quality decay, the combined effects of natural antioxidants and storage temperature on peroxidase activity and sensory attributes (overall visual quality, browning and odor) of individual and mixed vegetables for soup (butternut squash, leek and celery) were evaluated. Fresh cut vegetables were treated with antioxidant solutions as tea tree essential oil $(15 \mu \mathrm{l} / \mathrm{mL})$, propolis extract $(15 \mu \mathrm{l} / \mathrm{mL})$ and gallic acid $(2 \mathrm{mg} / \mathrm{mL})$ and stored at optimal $\left(5^{\circ} \mathrm{C}\right)$ and abusive $\left(15^{\circ} \mathrm{C}\right)$ temperature for a maximum of 14 days. The application of natural preservatives, plus optimal storage conditions, exerted significant inhibitory effects in peroxidase activity of squash, celery and mixed vegetables throughout the storage. Furthermore, propolis treatment applied on mixed vegetables retarded browning appearance and preserved the visual quality for a longer period when compared to untreated product.
\end{abstract}

Keywords: ready to use vegetables; antioxidants; bioactive compounds; shelf life; preservation technologies; quality changes.

Practical Application: The application of natural antioxidants such as propolis extract in combination with optimal storage conditions may be a good alternative to minimize the possibilities of fresh cut vegetables deterioration and preserve their quality.

\section{Introduction}

In recent decades, the market share of processed vegetables has increased steadily. The processing of these products promotes their consumption but, as a consequence, their structural integrity is frequently altered (São José et al., 2014). Specifically, enzymatic browning in fruit and vegetable tissues can cause undesirable quality changes during handling, processing and storage. This reaction results mostly from polyphenol oxidase and peroxidase activity (Ponce et al., 2004). The enzymes present in most fresh foods have the capability of causing both undesirable and desirable changes; therefore, the knowledge about how they react is an important consideration in food technology. Peroxidase is a plant enzyme involved in multiple deteriorative changes affecting flavor, texture, color and nutrition in processed fruits and vegetables. Inhibition of plant enzymes is generally achieved using physical or chemical treatments such as heating (blanching), lowering $\mathrm{pH}$ or $\mathrm{a}_{\mathrm{w}}$ or incorporating chemical additives (Solgi \& Ghorbanpour, 2014). However, due to the consumer market being concerned about the use of chemicals in such products, more attention has been given to the search of alternative anti browning compounds (Garmakhany et al., 2010; Solgi \& Ghorbanpour, 2014). This has led to renewed interest in natural antioxidant products. Research and commercial applications have revealed that alternative antimicrobial solutions can replace traditional sanitizing agents (Silveira et al., 2010). The essential oil of tea tree (Melaleuca alternifolia), gallic acid and propolis all have shown a high level of antifungal and antimicrobial activities in various crops (Chanwitheesuk et al., 2007; Mertas et al., 2014).
However, there is little information about the effect of these natural compounds as anti browning agents.

Minimum safe low temperatures and high relative humidity control are some of the most important tools for extending the shelf life of most fresh vegetables. However, such low temperature is not always maintained throughout the entire cold chain in some countries, where wholesalers and retailers generally keep produce above the recommended temperature to save costs or due to the lack of energy and refrigeration equipment (Zhan et al., 2012).

The purpose of this study was to evaluate the feasible use of bioactive agents to reduce peroxidase activity on mixed vegetables and on the individual vegetable component. In this work, we evaluated the effects of three biopreservatives (tea tree, propolis extract and gallic acid) on peroxidase activity. Furthermore, we also evaluated the effect of these compounds on the sensory attributes of vegetable samples along the storage. Two storage temperatures $\left(5\right.$ and $\left.15^{\circ} \mathrm{C}\right)$ were chosen to simulate an optimal and abusive refrigerated storage, respectively.

\section{Materials and methods}

\subsection{Raw material}

Celery (Apium graveolens L.), leek (Allium porrum L.) and butternut squash (Cucurbita moschata, D.) cultivated in the open field were harvested and immediately transported 
to the laboratory in containers refrigerated with polyfreezer (refrigerated gel for maintaining cold chain, Thermics Argentina SA). Squashes of uniform size and color were selected and then peeled, washed thoroughly with tap water and diced (ca $15 \mathrm{~mm}$ ) with a stainless steel knife. Celery petioles and leeks were also washed and sliced (10 mm tickness). Processed vegetables were dipped in tap water $(3 \mathrm{~min})$ and the surface moisture was removed with a manual salad centrifuge. Individual vegetables and mixed vegetables (ratio 1:1:1) were placed in open plastic containers and then treated with different biopreservatives.

\subsection{Bioactive compounds application: samples treatment}

Bioactive compounds used in this work were: tea tree essential oil (Melaleuca alternifolia) purchased from Nelson and Russell (London, England), extract of propolis (Juricich, Argentina) and gallic acid (Sigma-Aldrich, Argentina). Tea tree essential oil was extracted by steam-distillation from tea tree leaves and the main compound determined by gas chromatography-mass spectrometry was terpinen-4-ol. Other minor constituents detected were $\gamma$-terpinene, $\alpha$-terpinene and p-cymene. Propolis extract was prepared from raw material collected in Mendoza (Argentina) province and the product was standardized to $10 \%$ propolis extract (dark brown color; total phenolic content $188 \mathrm{~g}$ gallic acid equivalents/ kg propolis).

These agents were added to mixed vegetables for soup as well as to each individual vegetable in the following concentrations: tea tree essential oil and propolis extract at $15 \mu \mathrm{l} / \mathrm{mL}$ and gallic acid at $2 \mathrm{mg} / \mathrm{mL}$. These concentrations were selected according to previous studies developed in order to test these agents as potential antimicrobials. Bioactive compounds were diluted in sterile distilled water and vigorously shaken at $30{ }^{\circ} \mathrm{C}$ for $30 \mathrm{~min}$ to obtain reasonably stable dispersions. Minimally processed vegetables were hand-sprayed with prepared solutions $(4 \mathrm{~mL}$ per container) and finally covered with a $15 \mu \mathrm{m}$ polyethylene wrap and sealed. In control samples, vegetables were sprayed with sterile distilled water. The containers were placed in holding boxes at a relative humidity of $95 \%$ and at two storage temperatures, 5 and $15{ }^{\circ} \mathrm{C}$, for a maximum of 14 days. Three containers per treatment were removed from storage and used for peroxidase activity assay and two containers for sensory evaluation, at each sampling time. The experiment was conducted twice.

\subsection{Crude vegetables extract}

Ten grams of mixed vegetables or each individual vegetable component were chopped and homogenized with $30 \mathrm{~mL}$ of distilled water in a homogeinizer (Stomacher 400 LAB CIMA, Buenos Aires, Argentina) at high speed for $3 \mathrm{~min}$. All steps were carried out at $4{ }^{\circ} \mathrm{C}$. The slurry was filtered through two layers of cheesecloth and centrifuged during $15 \mathrm{~min}$ at $10000 \mathrm{~g}$ and $4{ }^{\circ} \mathrm{C}$. The supernatant, which contained peroxidase activity, was used as the enzyme source for the experiment (Ponce et al., 2004).

\subsection{Determination of enzyme activity}

Peroxidase activity was determined spectrophotometrically at $25^{\circ} \mathrm{C}$ with a UV-1601 PC UV-visible spectrometer (Shimadzu Corporation, Kioto, Japan) at $470 \mathrm{~nm}$ using guaiacol as substrate and $\mathrm{H}_{2} \mathrm{O}_{2}$ as hydrogen donor (Ong et al., 2013). The substrate mixture contained $10 \mathrm{~mL}$ of guaiacol solution at $0.01 \mathrm{ml} / \mathrm{mL}$, $10 \mathrm{~mL}$ of hydrogen peroxide solution at $3 \mathrm{mg} / \mathrm{mL}$ and $100 \mathrm{~mL}$ of $0.05 \mathrm{~mol} / \mathrm{L}$ sodium phosphate buffer ( $\mathrm{pH} 6.5$ ). The reaction cuvette contained $2.9 \mathrm{~mL}$ substrate mixture and $0.1 \mathrm{~mL}$ crude extract in a total volume of $3 \mathrm{~mL}$. In order to use the right levels of enzymatic activity, the assay volume was adjusted to an adequate dilution to ensure linearity of the assay. As peroxidase activity assay, using guaiacol as a substrate, is very sensitive and rapid, it is important to use the right levels of enzymatic activity in the extract. One unit of activity is defined as a change in absorbance of $0.001 / \mathrm{min}$ (Ponce et al., 2004). The blank sample contained only $3 \mathrm{~mL}$ of substrate mixture. Extractions and POD activity determinations were conducted using three separate replicates (three containers) per treatment at each storage time. These assays were developed until vegetable samples reached the end of shelf life evaluated by the panel of judges.

\subsection{Descriptive sensory analysis and shelf life}

At each storage time, individual and mixed vegetables (untreated and treated with natural agents) were subjected to sensory evaluation by a panel of testers. A panel comprised of nine members of the UNMdP Food Engineering Group, aged 30-50 years, and with sensory evaluation experience in vegetable quality, evaluated the quality of celery, leek and butternut squash. Preliminary tests were carried out to identify those defects most likely to appear due to prolonged storage of fresh cut butternut squash, celery and leek. Then, the panel defined three critical sensory attributes to be evaluated on individual and mixed vegetables, such as overall visual quality (OVQ), browning and odor and also agreed on the methods to evaluate these attributes. OVQ included attributes perceived with view as freshness, surface brightness, uniformity of color and texture. The panelists were trained by measuring samples stored at 5 and $15^{\circ} \mathrm{C}$ with different storage times using $5-\mathrm{cm}$ unstructured intensity scales.

For the experiment, the coded (3 digit) samples (60 g) were presented in random order to the members that made independent evaluations. Evaluations were performed under artificial daylight-type illumination, at room temperature $\left(22-24^{\circ} \mathrm{C}\right)$. The intensity of the sensory attributes evaluated was quantified on a $5-\mathrm{cm}$ unstructured intensity scale. OVQ was scored from 0 (highly deteriorated aspect) to 5 (fresh aspect). Browning was rated from 0 (very severe) to 5 (no presence) and odor from 0 (intense off odor) to 5 (fresh). The limit of acceptance was 2.5 (value corresponding to $50 \%$ of the scale), indicating that a score below this limit for any of the attributes evaluated was deemed to indicate end of shelf life (Alvarez et al., 2013; Jacxsens et al., 2002).

\subsection{Statistical analysis}

The results showed in this study are expressed as mean values with their standard deviations. Experiments were developed at two storage temperatures $\left(5\right.$ and $\left.15^{\circ} \mathrm{C}\right)$ and were established with two factors (antioxidant treatment and storage time) using a completely randomized design. Antioxidant treatments include tea tree essential oil, propolis and gallic acid applications. Storage time was defined in six levels $(0,2,5,7,10$ 
and $14 \mathrm{~d}$ ). The ANOVA was performed to analyze the data for each experiment and the Tukey-Kramer multiple-comparison test was used for analysis of treatments comparisons. Wherever differences are reported as significant, a 95\% confidence level was used. The data was analyzed using R 2.12.2 statistical software (2010).

\section{Results and discussion}

\subsection{Initial POD activity on mixed vegetables and individual vegetable components}

The initial peroxidase activity of untreated samples of squash, leek and celery crude extracts and their combination for soup was presented in Table 1. As it can be seen, significant differences were found between the initial peroxidase activities in these vegetables. Our results revealed that peroxidase activity of butternut squash and celery was significantly lower when compared with leek POD activity. Besides, the great variability in POD activity in fresh raw material might be attributed to intrinsic factors and to pre- and post-harvest factors. Variables such as field conditions, handling during transportation or maturation stage may influence physiologic events that take place before browning (Ponce et al., 2004).

\subsection{Evolution of POD activity on mixed vegetables and individual vegetable components during storage}

The cutting operations involved in the preparation of vegetable soup causes a great number of cells to be disrupted, which in turn causes the release of enzymes and their substrates, and increases the possibilities of oxidative enzyme-catalyzed processes during storage. Due to the vegetable enzyme composition complexity, the individual peroxidase activity of each vegetable component should always be studied because of the possible synergistic or antagonistic interaction among peroxidase activity in mixed vegetables.

The evolution of individual POD activity of butternut squash, leek and celery during storage at 15 and $5{ }^{\circ} \mathrm{C}$ are shown in Figure $1(\mathrm{a}, \mathrm{b}, \mathrm{c})$ and Figure $2(\mathrm{a}, \mathrm{b}, \mathrm{c})$, respectively. The evolution of mixed vegetables' POD activity during storage at 15 and $5{ }^{\circ} \mathrm{C}$ are shown in Figure $1 \mathrm{~d}$ and Figure $2 \mathrm{~d}$, respectively. Obtained data were analyzed to evaluate the effect of factors as antioxidant treatment and storage time on POD activity in fresh cut squash, leek, celery and in mixed vegetables stored at 5 and $15{ }^{\circ} \mathrm{C}$. As expected, optimal refrigerated storage temperature greatly reduced peroxidase activity of vegetables when compared

Table 1. Initial values of peroxidase activity in crude vegetable extracts without treatments (control samples).

\begin{tabular}{lc}
\hline \multicolumn{1}{c}{ Vegetable } & $\begin{array}{c}\text { Initial peroxidase activity } \\
\text { (units/min/g vegetable) }^{\mathrm{a}}\end{array}$ \\
\hline Celery & $2932 \pm 538 \mathrm{a}$ \\
Butternut squash & $2910 \pm 590 \mathrm{a}$ \\
Leek & $8194 \pm 1068 \mathrm{~b}$ \\
Vegetable mix & $7962 \pm 264 \mathrm{~b}$ \\
\hline
\end{tabular}

${ }^{a}$ Data represent mean values \pm standard deviation of six determinations. Means followed by different letters are significantly different $(P<0.05)$. to those stored at abusive temperature. These results were reflected in the organoleptic quality of the products.

Storage time represented a significant factor $(P<0.05)$ that affected POD activity of individual and mixed vegetables. POD activity mean values significantly rise as storage time increased and this effect resulted more significant when samples were stored at $15^{\circ} \mathrm{C}$ (Figure 1) compared to $5^{\circ} \mathrm{C}$ (Figure 2).

The response of peroxidase activity to the antioxidant treatment was different in each vegetable substrate studied and depended on the storage conditions. It is well known that refrigerated storage is a critical factor in the preservation of fresh cut vegetables (Siddiqui et al., 2011). However, the application of biopreservatives was tested in the present study as an additional barrier in order to enhance the peroxidase inhibitory effect of cooling or exert a protective effect against a possible temperature abuse. $0-5{ }^{\circ} \mathrm{C}$ is usually a desirable storage temperature for most fresh-cut products. However, the fact is that many of them are shipped and marketed at temperatures exceeding optimal temperature like $10-15{ }^{\circ} \mathrm{C}$.

Significant antioxidant effects were observed at abusive temperature and towards the end of shelf life of vegetables. However, when vegetables were stored at optimal temperature $\left(5^{\circ} \mathrm{C}\right)$ significant inhibitory effects were also detected and generally these effects were maintained throughout the storage. With regard to minimally processed squash, it was observed a significant decrease $(P<0.05)$ of POD activity in samples treated with tea tree and gallic acid (34 and 29\% POD activity reduction when compared to control, respectively) at 10 days of storage at $15^{\circ} \mathrm{C}$ (Figure 1a). At $5{ }^{\circ} \mathrm{C}$, all applied agents were effective in reducing POD activity in butternut squash, reaching $32-49 \%$ reductions at days 7 and 10 of refrigerated storage (Figure 2a). In leek samples stored at $15^{\circ} \mathrm{C}$, a similar effect of antioxidant treatments was observed in POD activity at the end of storage (18 and $24 \%$ reduction with tea tree and gallic acid respectively) (Figure $1 \mathrm{~b}$ ). On the contrary, no significant inhibitory effects were observed in POD activity of leek stored at optimal refrigeration temperature $\left(5^{\circ} \mathrm{C}\right)$ (Figure $2 \mathrm{~b}$ ).

The antioxidant properties of tea tree essential oil and its components were studied by Kim et al. (2004) who demonstrated that $\alpha$-terpinene, $\gamma$-terpinene and $\alpha$-terpinolene had the largest antioxidant capacity. Ponce et al. (2004) demonstrated the effectiveness of several essential oils including tea tree in reducing peroxidase activity of leafy vegetables by in vitro assays. Moreover, gallic acid is a natural phenolic compound extractable from plants, especially green tea and grapes and its antioxidant properties were well demonstrated (Lu et al., 2006, Maqsood et al., 2014).

POD activity in fresh cut celery stored at $15^{\circ} \mathrm{C}$ remained at a low level compared to the rest of the vegetables, although it was observed a slight but significant effect of propolis $(17 \%$ reduction) at 7 days of storage (Figure 1c). When celery samples were stored at $5{ }^{\circ} \mathrm{C}$, propolis treatment reduced significantly POD activity throughout the storage. At day 10, POD activity in celery treated with propolis was $32 \%$ lower when compared to untreated sample (Figure 2c). As far as we know, there are no reports in the scientific literature about the activity of propolis 
(a)

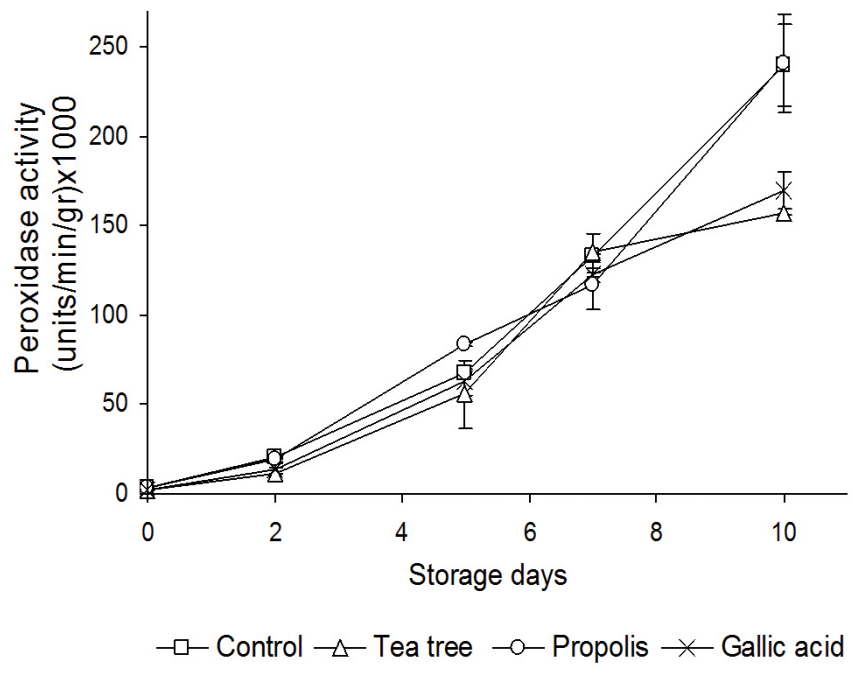

(c)

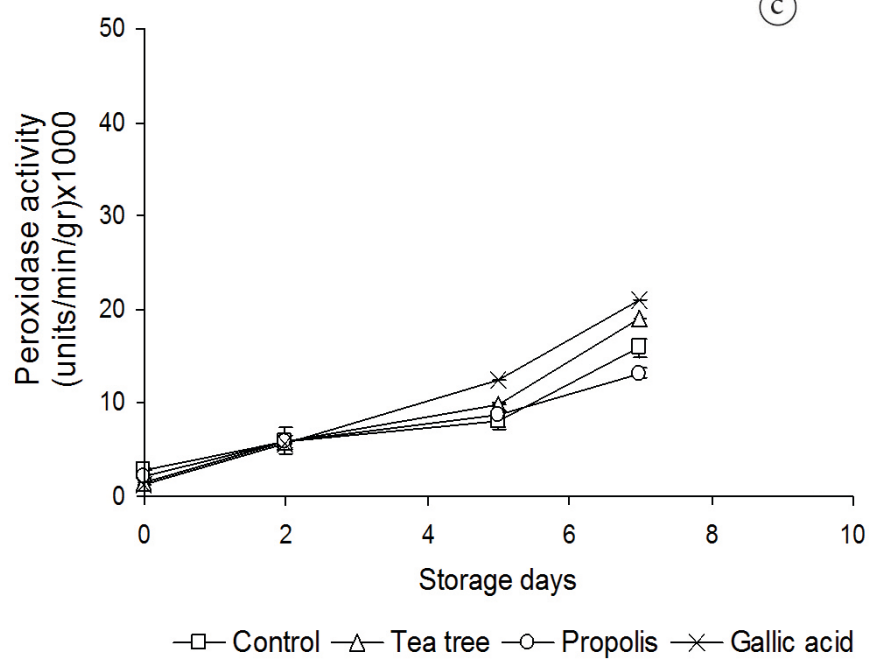

(b)

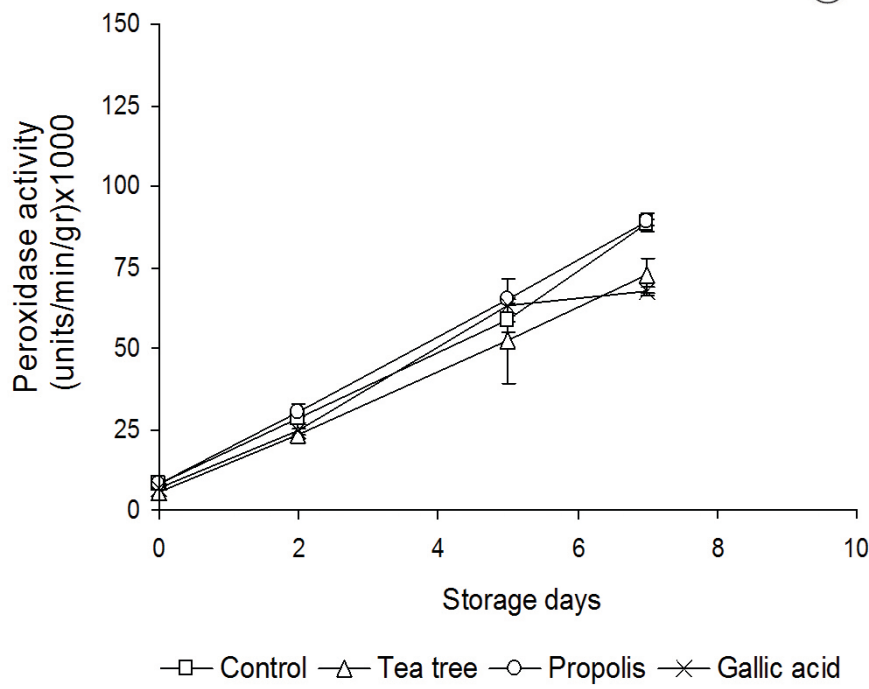

(d)

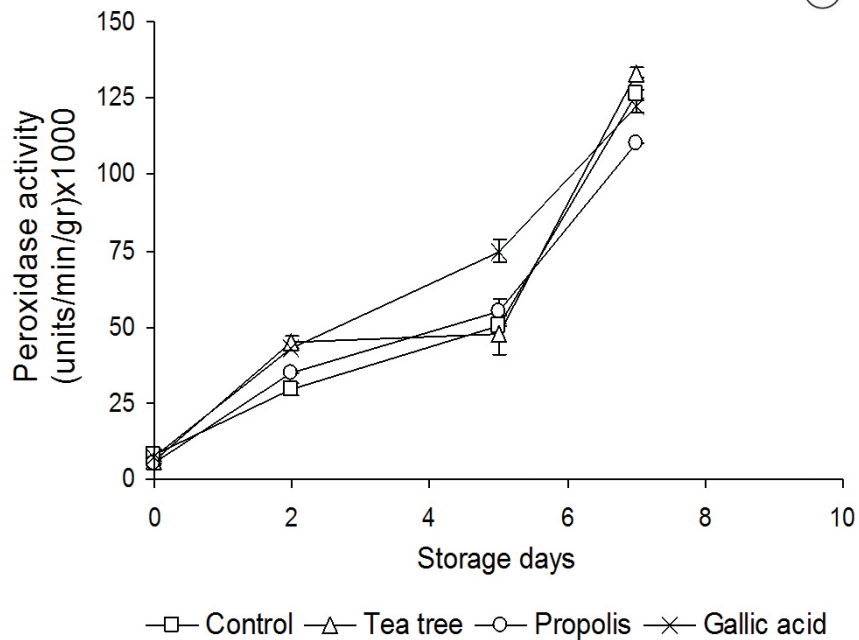

Figure 1. Changes in peroxidase activity of fresh cut vegetables treated with biopreservatives and stored at $15^{\circ} \mathrm{C}$ for up to $7-10$ days. (a) Butternut squash. (b) Leek. (c) Celery. (d) Mix of vegetables. Error bars indicate the standard deviation of six determinations.

as an inhibitor of plant peroxidase. The antioxidative properties of propolis were reported by Kurek-Górecka et al. (2013) who associated this activity with the presence of flavonoids, such as quercetin, flavones, isoflavones, flavonones, catechin, and isocatechin.

The results obtained after the application of antioxidants on mixed vegetables were not correlated with those obtained for the components treated individually. Gallic acid and tea tree treatments were not effective in reducing peroxidase activity in the mixed vegetables for soup stored at $15^{\circ} \mathrm{C}$ (Figure 1d). However, a slight but significant $(P<0.05)$ effect of propolis was observed at 7 days when vegetables were stored at $15 \mathrm{C}$ (13\% reduction) (Figure $1 \mathrm{~d}$ ). At $5{ }^{\circ} \mathrm{C}$, propolis and gallic acid treatments significantly $(P<0.05)$ reduced POD activity in mixed vegetables and these effects were only observed at days 5 and 7.

\subsection{Sensory evaluation and sensory shelf life of minimally processed vegetables}

At the moment of purchase the consumer relates appearance factors with freshness and, therefore, appearance is considered one of the most critical quality attributes (Kasim \& Kasim, 2014). To optimize the application of natural preservatives to extend shelf life of fresh cut vegetables, sensory analyses were developed to monitor changes on organoleptic properties during storage. As mentioned earlier, sensory shelf life was considered as finished when the product attributes drop below the acceptance limit which is equal to $50 \%$ of the evaluation scale (2.5). The evolution of OVQ scores obtained for individual components and for mixed vegetables, treated with biopreservatives and stored at $15^{\circ} \mathrm{C}$ and $5{ }^{\circ} \mathrm{C}$ are shown in Figure 3 (a, b, c and d) and Figure 4 (a, b, c and d), respectively. 

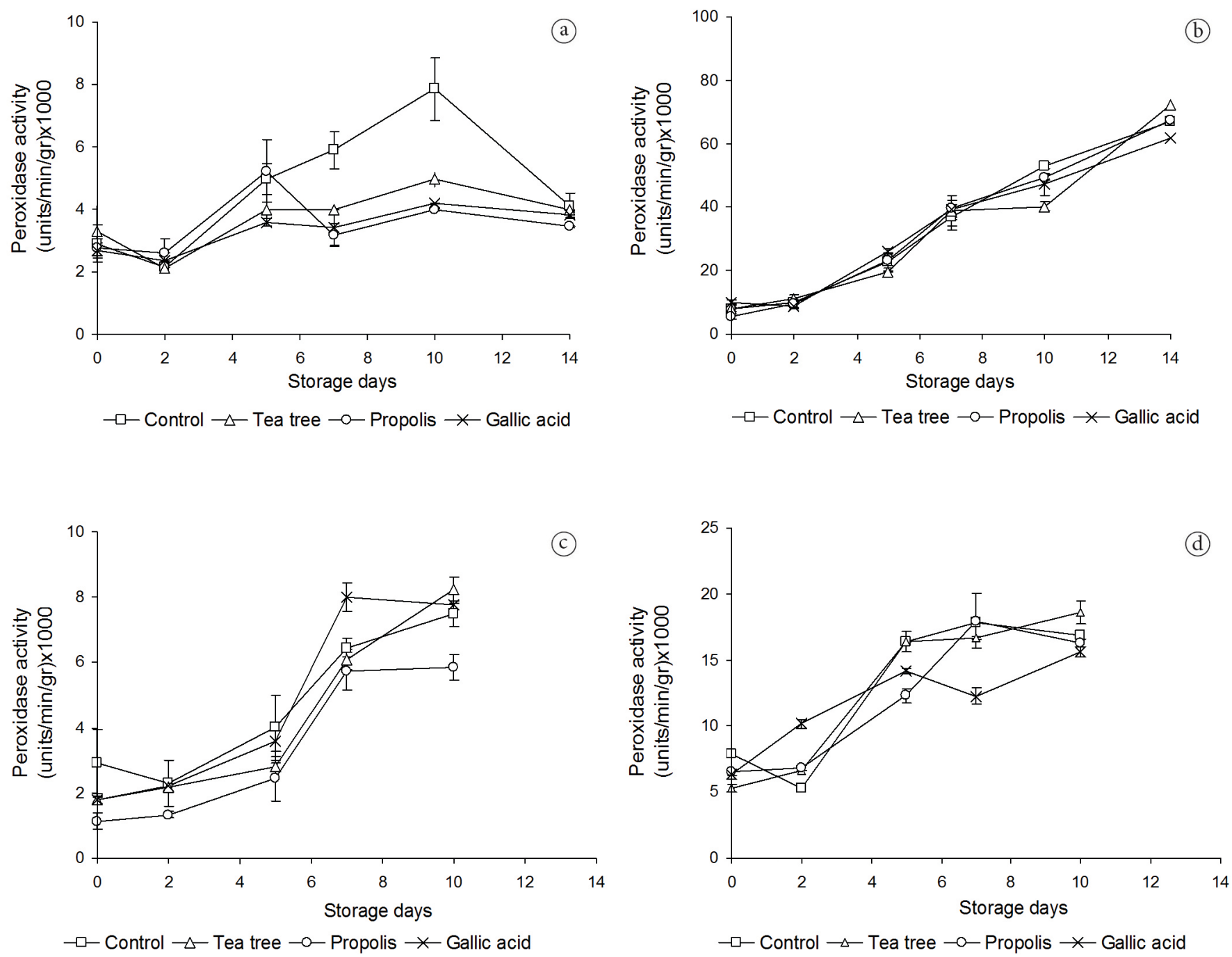

Figure 2. Changes in peroxidase activity of fresh cut vegetables treated with biopreservatives and stored at $5^{\circ} \mathrm{C}$ for up to $10-14$ days. (a) Butternut squash. (b) Leek. (c) Celery. (d) Mix of vegetables. Error bars indicate the standard deviation of six determinations.

OVQ scores of fresh cut vegetables decreased with increasing storage periods, at 15 and $5{ }^{\circ} \mathrm{C}$ (Figures 3 and 4). Cold storage during distribution and retailing is necessary for the prevention of browning in fresh-cut vegetables, since refrigerated temperatures are effective in lowering the activities of browning-related enzymes, as was demonstrated for POD activity in the previous section.

At abusive temperature, butternut squash, leek and celery control samples showed acceptable OVQ scores until 7, 5 and 2 days respectively (Figure $3 \mathrm{a}, \mathrm{b}$ and $\mathrm{c}$ ). The main factors affecting the quality of these vegetables were fast loss of fresh appearance, color deterioration and severe browning appearance. The mix of vegetables, under the same storage conditions, showed a sensory shelf life of 5 days, limited by celery deterioration (Figure 3d, Table 2). At $5{ }^{\circ} \mathrm{C}$, butternut squash, leek and celery control samples (without the addition of bioactive agents) showed acceptable OVQ scores up to days 10,10 and 14 of storage, respectively (Figure $4 \mathrm{a}, \mathrm{b}$ and c). However, mixed vegetables, stored at $5{ }^{\circ} \mathrm{C}$, showed acceptable visual quality for a shorter period, 7 days (Figure 4d). Celery proved to be the specie limiting shelf life of the mix, due to emergence of browning and loss of texture.

The impact of applied biopreservatives on the appearance of minimally processed vegetables varied depending on vegetable type, storage time and temperature. In this regard, fresh cut squash treated with tea tree essential oil, at $5{ }^{\circ} \mathrm{C}$, showed an OVQ score significantly higher than control sample $(P<0.05)$ and this treatment allowed to extend shelf life from 10 to 14 days (Figure 4a). This fact could be related to the peroxidase inhibitory effect of tea tree observed during refrigerated 

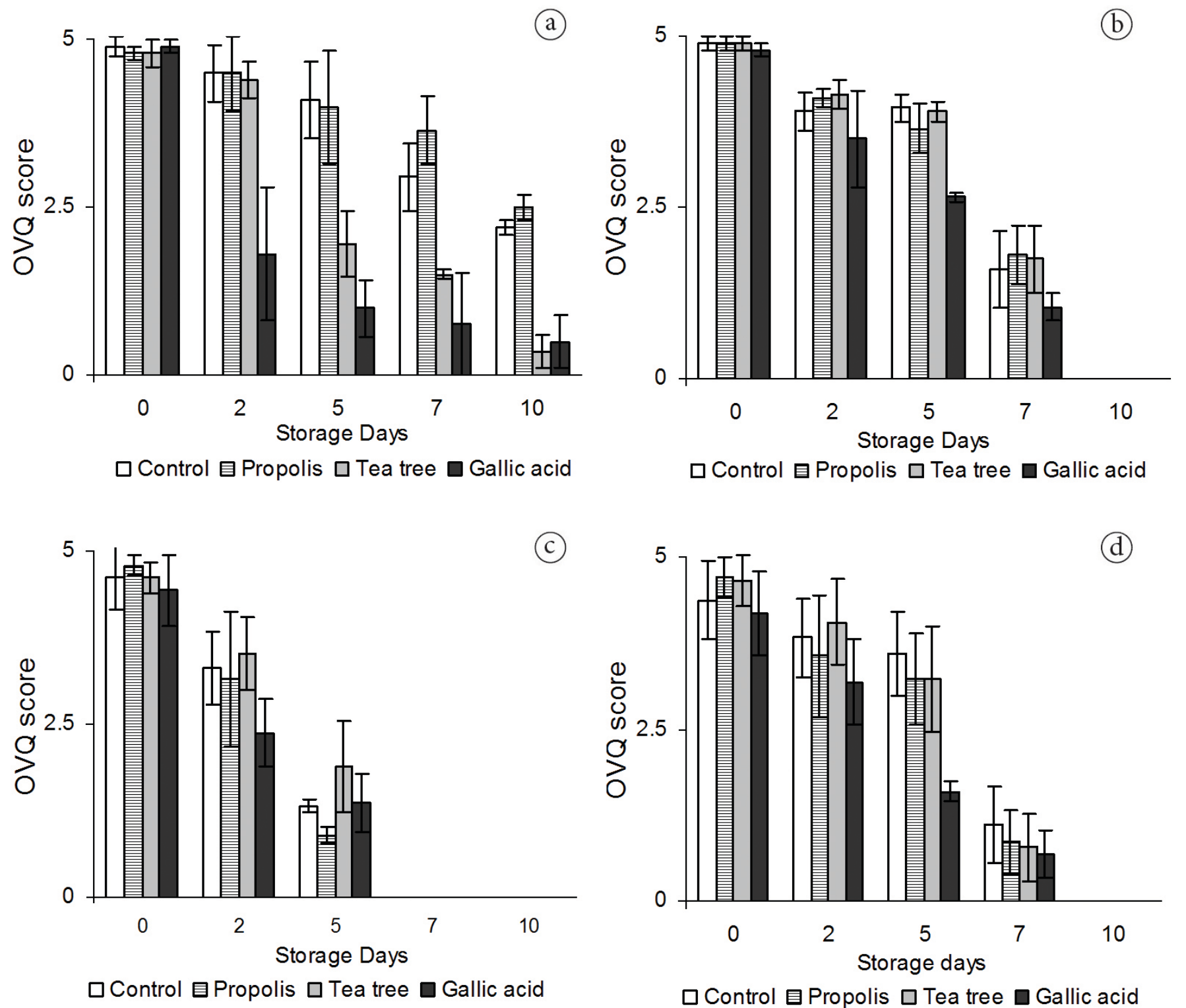

Figure 3. Overall visual quality evolution of individual and mixed fresh cut vegetables treated with biopreservatives and stored at $15{ }^{\circ} \mathrm{C}$. (a) Butternut squash. (b) Leek. (c) Celery. (d) Mix of vegetables. 0 score means "highly deteriorated aspect" and 5 means "fresh aspect" in a 5 -cm unstructured scale. Error bars indicate the standard deviation.

storage of butternut squash. Also, this preservative could be exerting an inhibitory effect on the growth of native microflora of butternut squash and delaying microbial spoilage. When OVQ of refrigerated leek samples was evaluated, none of the treatments showed differences compared to control $(P<0.05)$ during storage (Figure $4 \mathrm{~b}$ ). On the contrary, overall visual quality of celery, at $5{ }^{\circ} \mathrm{C}$, was positively affected by propolis treatment, OVQ being significantly higher than that of control sample at 10 days of storage (Figure 4c). Propolis treatment was able to retard browning appearance in fresh cut celery, and it is confirmed by browning scores showed in Table 2. The addition of propolis solution to the mix of vegetables was the only treatment able to extend its sensory shelf life (from 7 to 10 days). OVQ scores obtained at 10 days of refrigerated storage remained higher than acceptability level (2.5) showing significant differences $(P<0.05)$ compared to control and other antioxidant treatments (Figure 4d). This finding is supported by other results previously described, as the effectiveness of propolis in retarding browning appearance in celery (Table 2) and also reducing POD activity of fresh cut butternut squash and celery stored at $5{ }^{\circ} \mathrm{C}$. There are no reports in the scientific literature about the use of propolis as anti browning agent to preserve quality of fresh cut fruits and vegetables.

In addition, when minimally processed vegetables treated with bioactive agents were kept under abusive temperature conditions $\left(15^{\circ} \mathrm{C}\right)$, none of the treatments resulted effective in extending shelf life or improving the organoleptic quality 

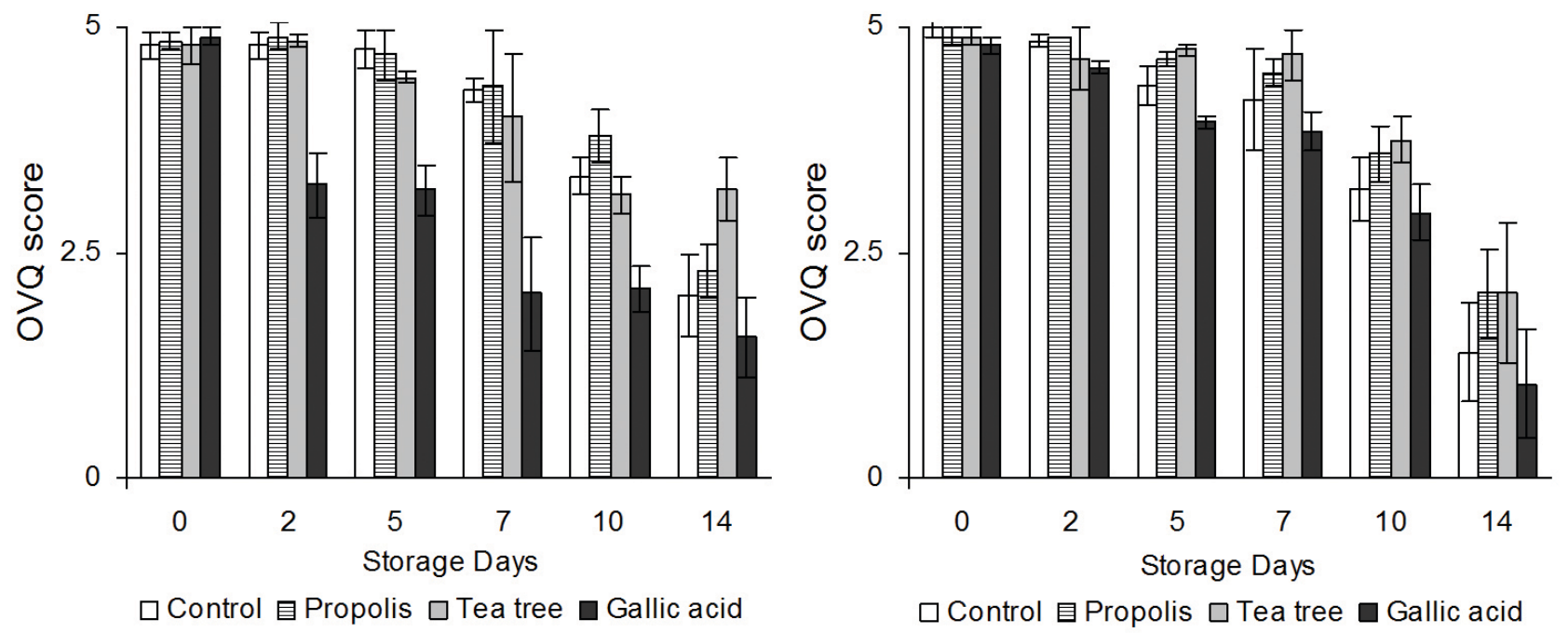

(C)
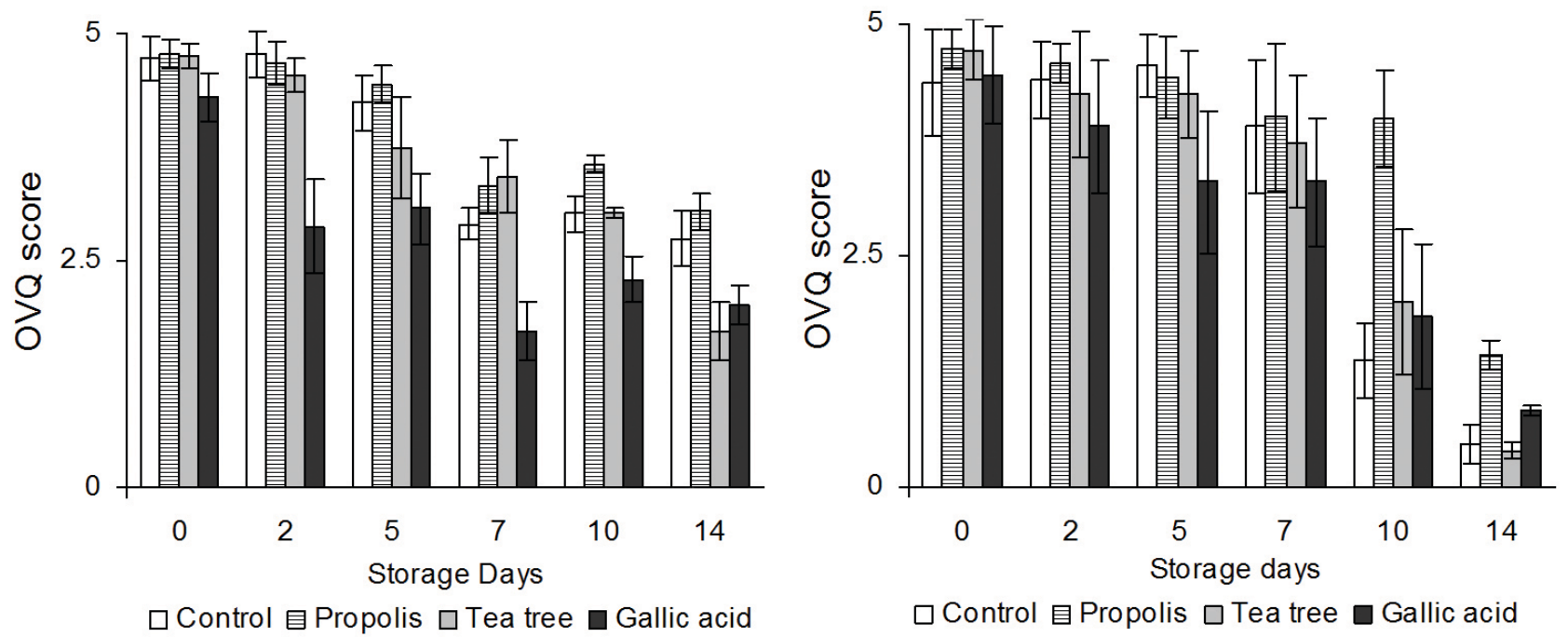

Figure 4. Overall visual quality evolution of individual and mixed fresh cut vegetables treated with different biopreservatives and stored at $5^{\circ} \mathrm{C}$. (a) Butternut squash. (b) Leek. (c) Celery. (d) Mix of vegetables. 0 score means "highly deteriorated aspect" and 5 means "fresh aspect" in a 5-cm unstructured scale. Error bars indicate the standard deviation.

(Figure 3). Probably, preservation effects of bioactive agents applied could be masked by this accelerated decay.

Moreover, gallic acid treatments were not effective in maintaining visual quality of fresh cut vegetables at the concentration tested in this study. In addition, gallic acid applied to butternut squash and celery introduced deleterious effects in visual quality, causing evident decreases in OVQ scores at $2 \mathrm{~d}$ of storage at 15 and $5{ }^{\circ} \mathrm{C}$ (Figure $3 \mathrm{a}$ and c; Figure 4a and c). The addition of gallic acid accelerates browning reactions on the surface of fresh cut celery and squash at both temperatures probably by the fact that this phenolic compound may act as substrate of polyphenol oxidase enzyme (Brewer, 2013).
Off flavors may be produced through the action of enzymes such as lipoxygenase or peroxidase throughout storage period. An important challenge in fresh cut vegetables handling is to maintain taste and aroma attributes of the original whole product (Wasim et al., 2011). Odor evaluations of fresh cut squash, leek, celery and mixed vegetables, treated with natural agents and stored at 5 and $15^{\circ} \mathrm{C}$ were carried out. Off odors in control samples (without biopreservatives) were detected later in vegetables stored at $5{ }^{\circ} \mathrm{C}$ compared to those stored at $15^{\circ} \mathrm{C}$. None of the treatments were able to delay the development of off odors when compared to coresponding untreated controls stored at 5 and $15{ }^{\circ} \mathrm{C}$ (data not shown). Gallic acid treatment negatively affected aroma in butternut squash, leek and celery 
Table 2. Browning evaluation of fresh cut butternut squash, leek, celery and mixed vegetables treated with natural preservatives and stored at 5 and $15^{\circ} \mathrm{C}$.

\begin{tabular}{|c|c|c|c|c|c|c|c|c|c|}
\hline \multirow{3}{*}{ Time } & \multirow{3}{*}{ Treatment } & \multicolumn{8}{|c|}{ Browning $^{\mathrm{a}}$} \\
\hline & & \multicolumn{2}{|c|}{ Butternut squash } & \multicolumn{2}{|c|}{ Leek } & \multicolumn{2}{|c|}{ Celery } & \multicolumn{2}{|c|}{ Mixed vegetables } \\
\hline & & $5^{\circ} \mathrm{C}$ & $15^{\circ} \mathrm{C}$ & $5^{\circ} \mathrm{C}$ & $15^{\circ} \mathrm{C}$ & $5{ }^{\circ} \mathrm{C}$ & $15^{\circ} \mathrm{C}$ & $5^{\circ} \mathrm{C}$ & $15^{\circ} \mathrm{C}$ \\
\hline \multirow[t]{3}{*}{0 days } & Control & $4.9 \pm 0.1 \mathrm{a}$ & $5.0 \pm 0.1 \mathrm{a}$ & $5.0 \pm 0.0 \mathrm{a}$ & $4.9 \pm 0.1 \mathrm{a}$ & $4.7 \pm 0.2 \mathrm{a}$ & $4.7 \pm 0.1 \mathrm{a}$ & $4.7 \pm 0.2 \mathrm{a}$ & $4.8 \pm 0.2 \mathrm{a}$ \\
\hline & Tea tree & $5.0 \pm 0.0 \mathrm{a}$ & $5.0 \pm 0.0 \mathrm{a}$ & $5.0 \pm 0.0 \mathrm{a}$ & $5.0 \pm 0.0 \mathrm{a}$ & $4.8 \pm 0.1 \mathrm{a}$ & $4.6 \pm 0.2 \mathrm{a}$ & $4.9 \pm 0.2 \mathrm{a}$ & $4.9 \pm 0.1 \mathrm{a}$ \\
\hline & Gallic acid & $4.9 \pm 0.1 \mathrm{a}$ & $4.9 \pm 0.1 \mathrm{a}$ & $4.9 \pm 0.1 \mathrm{a}$ & $4.9 \pm 0.1 \mathrm{a}$ & $3.9 \pm 0.2 b$ & $4.4 \pm 0.3 \mathrm{a}$ & $4.8 \pm 0.2 \mathrm{a}$ & $4.3 \pm 0.3 \mathrm{a}$ \\
\hline \multirow{2}{*}{2 days } & Tea tree & $4.9 \pm 0.1 \mathrm{a}$ & $4.8 \pm 0.1 \mathrm{a}$ & $4.8 \pm 0.3 \mathrm{a}$ & $4.7 \pm 0.4 \mathrm{a}$ & $4.4 \pm 0.3 \mathrm{a}$ & $3.3 \pm 0.6 \mathrm{a}$ & $4.3 \pm 0.6 \mathrm{a}$ & $4.3 \pm 0.6 \mathrm{a}$ \\
\hline & Gallic acid & $3.5 \pm 0.7 \mathrm{~b}$ & $1.6 \pm 0.6 \mathrm{~b}$ & $4.7 \pm 0.1 \mathrm{a}$ & $3.5 \pm 0.4 b$ & $2.7 \pm 0.8 \mathrm{~b}$ & $2.2 \pm 0.7 \mathrm{a}$ & $4.2 \pm 0.4 \mathrm{a}$ & $3.6 \pm 0.7 \mathrm{a}$ \\
\hline \multirow[t]{3}{*}{5 days } & Control & $4.8 \pm 0.1 \mathrm{a}$ & $4.8 \pm 0.2 \mathrm{a}$ & $4.5 \pm 0.1 \mathrm{a}$ & $4.2 \pm 0.3 \mathrm{a}$ & $4.5 \pm 0.4 \mathrm{a}$ & $1.5 \pm 0.4 \mathrm{a}$ & $4.4 \pm 0.4 \mathrm{a}$ & $3.3 \pm 0.7 \mathrm{a}$ \\
\hline & Propolis & $4.9 \pm 0.1 \mathrm{a}$ & $4.0 \pm 0.8 \mathrm{a}$ & $4.7 \pm 0.4 \mathrm{a}$ & $3.3 \pm 0.1 \mathrm{ab}$ & $4.3 \pm 0.2 \mathrm{a}$ & $0.6 \pm 0.4 \mathrm{a}$ & $4.2 \pm 0.6 \mathrm{a}$ & $3.2 \pm 0.7 \mathrm{a}$ \\
\hline & Tea tree & $4.7 \pm 0.4 \mathrm{a}$ & $4.1 \pm 0.4 \mathrm{a}$ & $4.7 \pm 0.1 \mathrm{a}$ & $2.9 \pm 0.9 \mathrm{ab}$ & $4.0 \pm 0.4 \mathrm{ab}$ & $1.1 \pm 0.7 \mathrm{a}$ & $3.7 \pm 0.7 \mathrm{a}$ & $2.9 \pm 0.5 \mathrm{a}$ \\
\hline \multirow{2}{*}{7 days } & Tea tree & $4.2 \pm 0.9 \mathrm{a}$ & $4.0 \pm 0.2 \mathrm{a}$ & $4.9 \pm 0.2 \mathrm{a}$ & $2.4 \pm 0.5 \mathrm{a}$ & $3.2 \pm 0.6 \mathrm{a}$ & & $3.3 \pm 0.6 \mathrm{a}$ & $1.8 \pm 0.7 \mathrm{a}$ \\
\hline & Gallic acid & $2.6 \pm 0.8 \mathrm{~b}$ & $0.8 \pm 0.6 b$ & $4.7 \pm 0.1 \mathrm{a}$ & $1.2 \pm 0.4 b$ & $2.1 \pm 0.8 \mathrm{a}$ & & $3.2 \pm 0.5 \mathrm{a}$ & $1.4 \pm 0.7 \mathrm{a}$ \\
\hline \multirow[t]{4}{*}{10 days } & Control & $4.2 \pm 0.3 \mathrm{a}$ & $2.0 \pm 0.4 \mathrm{a}$ & $4.7 \pm 0.4 \mathrm{a}$ & & $3.7 \pm 0.3 \mathrm{a}$ & & $1.9 \pm 0.5 b$ & \\
\hline & Propolis & $4.2 \pm 0.4 \mathrm{a}$ & $1.6 \pm 0.2 \mathrm{ab}$ & $4.8 \pm 0.3 \mathrm{a}$ & & $4.2 \pm 0.2 \mathrm{a}$ & & $3.5 \pm 0.5 \mathrm{a}$ & \\
\hline & Tea tree & $4.1 \pm 0.2 \mathrm{a}$ & $2.0 \pm 0.3 \mathrm{a}$ & $4.7 \pm 0.3 \mathrm{a}$ & & $3.0 \pm 0.3 b$ & & $1.7 \pm 0.4 b$ & \\
\hline & Gallic acid & $3.2 \pm 0.3 b$ & $0.9 \pm 0.4 b$ & $4.7 \pm 0.2 \mathrm{a}$ & & $2.5 \pm 0.3 b$ & & $1.1 \pm 0.7 \mathrm{~b}$ & \\
\hline \multirow[t]{4}{*}{14 days } & Control & $3.3 \pm 0.2 b$ & & $3.4 \pm 0.3 \mathrm{a}$ & & $3.4 \pm 0.7 \mathrm{a}$ & & $0.6 \pm 0.3 \mathrm{a}$ & \\
\hline & Propolis & $3.5 \pm 0.1 \mathrm{~b}$ & & $2.6 \pm 0.9 \mathrm{a}$ & & $2.9 \pm 0.7 \mathrm{a}$ & & $1.5 \pm 0.7 \mathrm{a}$ & \\
\hline & Tea tree & $4.3 \pm 0.4 \mathrm{a}$ & & $3.4 \pm 0.3 \mathrm{a}$ & & $2.9 \pm 0.7 \mathrm{a}$ & & $1.0 \pm 0.6 \mathrm{a}$ & \\
\hline & Gallic acid & $2.2 \pm 0.1 \mathrm{c}$ & & $3.2 \pm 0.5 \mathrm{a}$ & & $2.1 \pm 0.5 \mathrm{a}$ & & $1.2 \pm 0.4 \mathrm{a}$ & \\
\hline
\end{tabular}

${ }^{a}$ Data represent mean score \pm standard deviation. 0 score means "very severe browning" and 5 means "no presence" in a 5-cm unstructured scale. Antioxidative treatments at each storage temperature and time of storage were compared. Means followed by different letters are significantly different $(\mathrm{P}<0.05)$.

and also in mixed vegetables when stored at $15{ }^{\circ} \mathrm{C}$ (data not shown).

\section{Conclusions}

In the present study, the application of potential antioxidant agents combined with refrigerated storage was tested in order to reduce peroxidase activity and preserve sensorial quality from the beginning and throughout the storage of individual and mixed vegetables. Strict temperature control of fresh cut produce is of eminent importance. The application of natural antioxidants, as tea tree essential oil, propolis extract and gallic acid, combined with optimal refrigeration temperature $\left(5^{\circ} \mathrm{C}\right)$ was able to significantly reduce peroxidase activity in fresh cut butternut squash, celery and mixed vegetables. Moreover, we demonstrated that the use of propolis extract sprayed on mixed vegetables delayed the appearance of browning and was able to extend sensory shelf life under refrigerated storage. Propolis treatment exerted a protective effect against browning on celery, vegetable specie limiting the sensory shelf life of the mixture for soup. On the contrary, gallic acid treatment negatively affected the visual quality and odor of fresh cut vegetables. Obtained results indicate that the application of natural antioxidants such as propolis extract in combination with optimal storage conditions may be a good alternative to minimize the possibilities of fresh cut vegetables deterioration and preserve their quality.

\section{Acknowledgements}

This work was supported by Consejo Nacional de Investigaciones Científicas y Técnicas and Universidad Nacional de Mar del Plata.

\section{References}

Alvarez, M. V., Ponce, A., \& Moreira, M. R. (2013). Antimicrobial efficiency of chitosan coating enriched with bioactive compounds to improve the safety of fresh cut broccoli. LWT. Food Science and Technology, 50(1), 78-87. http://dx.doi.org/10.1016/j. lwt.2012.06.021.

Brewer, S. (2013). Effect of oxidation sensory characteristics of food components during processing and storage. In G. Bartosz (Ed.), Food oxidants and antioxidants: chemical, biological, and functional properties (pp. 179). Boca Raton: CRC Press.

Chanwitheesuk, A., Teerawutgulrag, A., Kilburn, J., \& Rakariyatham, N. (2007). Antimicrobial gallic acid from Caesalpinia mimosoides Lamk. Food Chemistry, 100(3), 1044-1048. http://dx.doi. org/10.1016/j.foodchem.2005.11.008.

Garmakhany, A., Mirzaei, H., Aghajani, N., \& Kashiri, M. (2010). Investigation of natural essential oil antioxidant activity on 
peroxidase enzyme in selected vegetables. Journal of Agricultural Science and Technology, 4(3), 78-82.

Jacxsens, L., Devlieghere, F., \& Debevere, J. (2002). Temperature dependence of shelf-life as affected by microbial proliferation and sensory quality of equilibrium modified atmosphere packaged fresh produce. Postharvest Biology and Technology, 26(1), 59-73. http:// dx.doi.org/10.1016/S0925-5214(02)00004-2.

Kasim, R., \& Kasim, M. (2014). Biochemical and color changes of fresh-cut melon (Cucumis melo L. cv. Galia). treated with UVC. Food Science and Technology, 34(3), 547-551. http://dx.doi. org/10.1590/1678-457x.6398.

Kim, H. J., Chen, F., Wu, C., Wang, X., Chung, H. Y., \& Jin, Z. (2004). Evaluation of antioxidant activity of Australian tea tree (Melaleuca alternifolia) oil and its components. Journal of Agricultural and Food Chemistry, 52(10), 2849-2854. http://dx.doi.org/10.1021/jf035377d. PMid:15137824

Kurek-Górecka, A., Rzepecka-Stojko, A., Górecki, M., Stojko, J., Sosada, M., \& Świerczek-Zieba, G. (2013). Structure and antioxidant activity of polyphenols derived from propolis. Molecules, 19(1), 78-101. http://dx.doi.org/10.3390/molecules19010078. PMid:24362627

Lu, Z., Nie, G., Belton, P. S., Tang, H., \& Zhao, B. (2006). Structure-activity relationship analysis of antioxidant ability and neuroprotective effect of gallic acid derivatives. Neurochemistry International, 48(4), 263-274. http://dx.doi.org/10.1016/j.neuint.2005.10.010. PMid:16343693

Maqsood, S., Benjakul, S., Abushelaibi, A., \& Alam, A. (2014). Phenolic compounds and plant phenolic extracts as natural antioxidants in prevention of lipid oxidation in seafood: a detailed review. Comprehensive Reviews in Food Science and Food Safety, 13(6), 1125-1140. http://dx.doi.org/10.1111/1541-4337.12106.

Mertas, A., Garbusińska, A., Szliszka, E., Jureczko, A., Kowalska, M., \& Król, W. (2014). The influence of Tea Tree Oil (Melaleuca alternifolia) on fluconazole activity against fluconazole-resistant
Candida albicans strains. BioMed Research International. (Article ID 590470).

Ong, G., Yap, C., Maziah, M., \& Tan, S. (2013). Synergistic and antagonistic effects of zinc bioaccumulation with lead andantioxidant activities in Centella Asiatica. Sains Malaysiana, 42(11), 1549-1555.

Ponce, A., Del Valle, C., \& Roura, S. (2004). Natural essential oils as reducing agents of peroxidase activity in leafy vegetables. LWT-Food Science and Technology, 37(2), 199-204. http://dx.doi.org/10.1016/j. lwt.2003.07.005.

São José, J. F. B., Andrade, N. J., Ramos, A. M., Vanetti, M. C. D., Stringheta, P. C., \& Chaves, J. B. P. (2014). Decontamination by ultrasound application in fresh fruits and vegetables. Food Control, 45, 36-50. http://dx.doi.org/10.1016/j.foodcont.2014.04.015.

Siddiqui, M., Bhattacharjya, A., Chakraborty, I., \& Dhua, R. (2011). Benzylaminopurine improves shelf life, organoleptic quality and health-promoting compounds of fresh-cut broccoli florets. Journal of Scientific and Industrial Research, 70, 461-465.

Silveira, A., Aguayo, E., \& Artés, F. (2010). Emerging sanitizers and Clean Room packaging for improving the microbial quality of fresh-cut 'Galia' melon. Food Control, 21(6), 863-871. http://dx.doi. org/10.1016/j.foodcont.2009.11.017.

Solgi, J., \& Ghorbanpour, M. (2014). Application of essential oils and their biological effects on extending the shelf-life and quality of horticultural crops. Trakia Journal of Sciences, 2, 198-210.

Wasim, S., Chakraborty, I., Ayala-Zavala, J., \& Dhua, R. (2011) Advances in minimal processing of fruits and vegetables: a review. Journal of Scientific and Industrial Research, 70, 823-834.

Zhan, L., Hu, J., Li, Y., \& Pang, L. (2012). Combination of light exposure and low temperature in preserving quality and extending shelf-life of fresh-cut broccoli (Brassica oleracea L.). Postharvest Biology and Technology, 72, 76-81. http://dx.doi.org/10.1016/j. postharvbio.2012.05.001. 